\title{
The Relationships of Expectancy, Instrumentality and Valence for Motivation in Self-Employment: A Mediation of Entrepreneurial Motivation in Nigeria
}

\author{
Muhammad Adamu ${ }^{\mathbf{1 , 2}}$,Mahani Mohammad Abdu Shakur ${ }^{2}$
}

\begin{abstract}
${ }^{\mathbf{1}}$ Department of Business Management, Faculty of Economics and Business University Malaysia Sarawak, Malaysia ${ }^{2}$ Department of Business Administration, Faculty of Social and Management Sciences, Bauchi State UniversityNigeria.

Correspondence: Muhammad Adamu,Department of Business Management, Faculty of Economics and Business University Malaysia Sarawak, Malaysia
\end{abstract}

Received: January 19, 2018

Accepted: January 30, 2018

Online Published: April 4, 2018

\begin{abstract}
The aim of this article is to investigate the motivation of potential entrepreneurs toward the realization of a new business creation. Universally, it is evident that the motivation of potential entrepreneur stem from both the individual factors and the environment matched together to trigger entrepreneurial motivation. The Vroom's Expectancy Motivation Theory explains self-employment in terms of an individual's motivation and ability to start a business. Businesses are created by those with the motivation and capability to realize it. Based on the Vroom's expectancy motivation theory (1964), the new business start-up specific expectancy, instrumentality and valence are key components of entrepreneurial motivation and this translates into the efforts, behavior sand performance that would in the end lead to a new business start-up among the potential entrepreneurs. The methodology used in this research was based on a positivist philosophy that entails a deductive approach with a quantitative technique through a cross-sectional survey. The data were collected with a questionnaire as an instrument for the survey. To attain the objectives of this research, the data of this study were analyzed using PLS-SEM Path Algorithms, Bootstrap path coefficients and Sobel test statistics. The statistical significance of relevant path coefficients that are fundamental in measuring self-employment among potential entrepreneurs were assessed and evaluated. The results confirm the supposition that expectancy, instrumentality and valence enhance entrepreneurial motivation for a new business start-up. Furthermore, external factors such as vocational training, machinery/equipment and ICT's were also significantly found to exert an impact on the potential entrepreneur's new venture creation.
\end{abstract}

Keywords: Expectancy; Instrumentality; Valence; Entrepreneurial Motivation; Potential Entrepreneurs; SelfEmployment (New Business Start-Up); Nigeria.

\section{Introduction}

Despite an aggravated level of unemployment, the recent economic downturn has caused a major setback which results 'in much increase Potential entrepreneurs were left in a much more vulnerable situation, and which the possible solutions suggested is the motivation for a new business start-up (Hopp \& Sonderegger, 2015). Such motivation is expected to yield an inspiration for a greater zeal and courage to become self-employed. The purpose of this article is to understand how an individual's motivation(potential entrepreneur) is related to the realization of a new business start-up. Such understanding properly seeks the basic comprehension of the components and consequences of potential entrepreneur's motivation through the application of expectancy theory, more specifically, the valence-instrumentality-expectancy (VIE) approach. Consequently, scholars (Grilli, 2011; Klyver, Nielsen \& Evald, 2013; Fitzsimmons \& Douglas,2011; Karimi et al., 2017) in trying to understand the underlying factors that influence such a decision and choice of potential entrepreneurs, have put forth a great deal of effort. In the examination of choice between alternative actions, the Vroom's expectancy motivation theory argued that 
individuals are more likely to select the alternative that is most likely to maximize attractive outcomes (Gatewood, Shaver, Powers \& Garner, 2012).). Expressly, according to Vroom (1964), the decision to start a new venture is being an expected outcome by the potential entrepreneurs.

2 Literature Review

2.1 Entrepreneurial Motivation

The entrepreneurial motivation refers to the forces or drives within an entrepreneur that affects the direction, intensity, and persistence of voluntary behaviour as an entrepreneur. At this point, a motivated entrepreneur is expected to be willing to exert a particular level of effort to attain self-employment (Sozen et al, 2017). Previous shreds of empirical research on the role of the motivation of entrepreneurs have acknowledged the importance of such motivation. Scholars such as (Yushuai et al., 2014; Kisker, 2016; Isa \& Muhammad, 2015; Awruk \& Staniewski, 2015) who looked critically at the role of the motivation of entrepreneurs in their empirical research emphasized the importance of motivation of entrepreneurs for self-employment realization. The authors define business creation as the identification of business opportunities and access to appropriate resources for entrepreneurs. Sozen et al. (2017) emphasize that limited empirical research on the motivation of entrepreneurs is not an indication of the lack of relevance of entrepreneurial motivation as a research area. The researchers invoked for the influence of human motivation in the process of self-employment/business creation on developing a more realistic explanation of entrepreneurial motivation. The motivation of entrepreneurs is an important research field to explain the development of new ventures based in the field of entrepreneurship (Yushuai et al., 2014; Kisker, 2016). Moreover, according to Sozen et al. (2017), in order to offer support for job creation by creating the right environment for self-employment, the motivation of potential entrepreneurs must be understood to promote them in the environmental context. The motivation of potential entrepreneurs to start their own business, which have a high probability to establish a successful business supposed to be determined by the given support for self-employment within a nation's programme. The support of the government and relevant stakeholders would be of paramount importance to promote, directly the motivation of potential entrepreneurs to start their own businesses. Thus, through the effective motivation, the potential entrepreneurs may have the courage to exert a desired degree of effort, which may subsequently result in an effective realization of their self-employment objective (Klyver, Nielsen \& Evald, 2013)

2.2Expectancy

The expectancy has been explained ass whenever there is a behavior, an outcome is being expected to subsequently come-up (Vroom, 1964). The probability of achieving desired outcomes from an entrepreneur's perceptions when considering a new venture opportunity are fostered by several factors such as beliefs regarding personal skills and knowledge needed to take advantage of the entrepreneurial opportunity; experience with success or failure in similar activities; whether or not the person believes that they can collect the needed resources; beliefs about the competition, industry, and economy; and the individual's characteristics and moods (Fernandez-Serrano \& Romero, 2012). When an individual perceives that a particular course of action has a high likelihood of producing a desired outcome (e.g., such as the need for independence, the need for change, the need for poverty reduction, need for more financial gain, the desire for a better conditions of work, family commitments and demand/market for products, in the context of this research), the potential entrepreneurs are most likely to be attracted by such expected outcomes, and spurs much efforts to attain it Manolova, Brush, Edelman, \& Shaver, 2012). When potential entrepreneurs consider the likelihood and desirability of the outcomes of a potential new venture, they are increasingly more likely to pursue the opportunity when both variables are high (Shapiro, 2014).).

2.3Instrumentality

Efforts and performance as an instrumentality predetermines the potential entrepreneur's accomplishment of the expected outcome, value or valence upheld by the Vroom's expectancy motivation theory. The efforts ad performance fundamentally can be realized through the functions of the person and the environment (Vroom, 1978). The entrepreneurial traits possessed by a person, although seems to be a classical and a promising determinant of entrepreneurial behavior, the trait approach has found various linkages between personal characteristics and entrepreneurship, more important function of the environment is essential (Canevello, 2011). The pre-start-up stage includes those events which lead a potential entrepreneur to a new venture creation opportunity. It can involve varying degrees of efforts, performance and interaction with resources from the environment. Thus, traits such as transformationality, resilience and autonomy, as well as environmental factors such as financing, vocational training, machinery/equipment, ICTs and taxation incentives could play an important role in influencing them towards these efforts and performance as a motivation. Previous shreds of empirical research on the role of the motivation of entrepreneurs have acknowledged the importance of such interaction of person and the environment that would spark efforts and performance as a motivation. Scholars such as (Yushuai et al., 2014; Kisker, 2016; Isa, Abu Bakar \&Ahmad, 2016; Awruk \& Staniewski, 2015) who looked critically at the role of the motivation of entrepreneurs in 
their empirical research emphasized the importance of motivation of entrepreneurs for self-employment realization. The authors define business creation as the identification of business opportunities and access to appropriate resources for entrepreneurs. Sozen et al. (2017) emphasize that limited empirical research on the motivation of entrepreneurs is not an indication of the lack of relevance of entrepreneurial motivation as a research area. The researchers invoked for the influence of human motivation in the process of self-employment/business creation on developing a more realistic explanation of entrepreneurial motivation. The motivation of entrepreneurs is an important research field to explain the development of new ventures based in the field of entrepreneurship (Yushuai et al., 2014; Kisker, 2016).

2.4 Valence

The value or valence of the behavioral outcomes refers to the expected benefit, satisfaction, or desirability that a potential entrepreneur associates with an outcome (Vroom, 1964). Relatedly, potential entrepreneurs may consider a much-desired outcome when mulling over alternative options. The value placed on the outcomes may range from varieties of expected results. For example, an entrepreneur may look at the impact of the relationship with a new venture creation (Hsu et al., 2014). In the context of this research, the need for independence, the need for change, the need for poverty reduction, need for more financial gain, the desire for a better condition of work, family commitments and demand/market for products, in the context of this research, the potential entrepreneurs are most likely to be attracted by such expected outcomes, and consequently, exercising much efforts to attain it (Gatewood et al., 2012). New businesses are typically created to provide value to customers and to collect value (i.e. money) from customers. It is not surprising that one of the primary objectives of becoming an entrepreneur is to reap the financial rewards of the business (Gichuki et al., 2014).

if the expected financial returns are high in start-up decisions, it is expected that entrepreneurs will be more motivated to act (Karimi et al., 2017; Seibert \& DeGeest, 2017). However, many entrepreneurs are also motivated by outcomes that are more intrinsic in nature. The need for independence, family commitments, the desire for change, the need for poverty reduction, demand/market for products and the desire for a better condition of work were found to be significant contributors to the decision to become an entrepreneur (Hsu, Shinnar \& Powell, 2014).Henley (2007) considers entrepreneurs from their business or profession as individuals who earn no wage or salary on their own account and at risk, but by exercising much effort and derive their income from their selfemployment practice. Most particularly, from the developed world, and in recent years among countries, the figures for self-employment have been increasing (Fátima, 2012). There is a growing interest in self-employment, which can be translated by the fact that academic studies on self-employment have steadily been increasing over time (Thurik, Carree, Stel \& Audretsch, 2008). The decision to become an entrepreneur is traced to be a social and an economic issue, which mars resolve menace in a society through job creation (Kritikos, 2014) .It, improves individual's standards of living which generate value for themselves by identifying and selling new and more useful products and services through the creation of new businesses.

2.5 Self-employment

Self-employment is defined as the process of earning a living and income through using own capital or borrowed funds by utilizing own knowledge and intelligence to harness all resources efficiently and effectively (Evans et al., 2009). Self-employment is considered to be important and which translate into wealth creation, improvement in living standard as well as an overall expected reduction in poverty level. The practice of self-employment has been in an increase across the globe. It was initially trade by barter which is the exchange of goods for goods or services was solely the practice, but with global economic evolution, money has replaced the trade by barter exchanges. Henley (2007) considers the self-employed from their business or profession as individuals who earn no wage or salary on their own account and at risk, but by exercising much effort and derive their income from their selfemployment practice. Most particularly, from the developed world, and in recent years among countries, the figures for self-employment have been increasing (Fátima, 2012). There is a growing interest in self-employment, which can be translated by the fact that academic studies on self-employment have steadily been increasing over time (Thurik, Carree, Stel \& Audretsch, 2008). The decision to become an entrepreneur is traced to be a social and an economic issue. For these reasons, autonomy and self-reliance after becoming self-employed may resolve the issues of social and economic menace in a society through job creation (Kritikos, 2014). It increases individual's standards of living which generate value for themselves by identifying and selling new and more useful products and services through the creation of new businesses. 


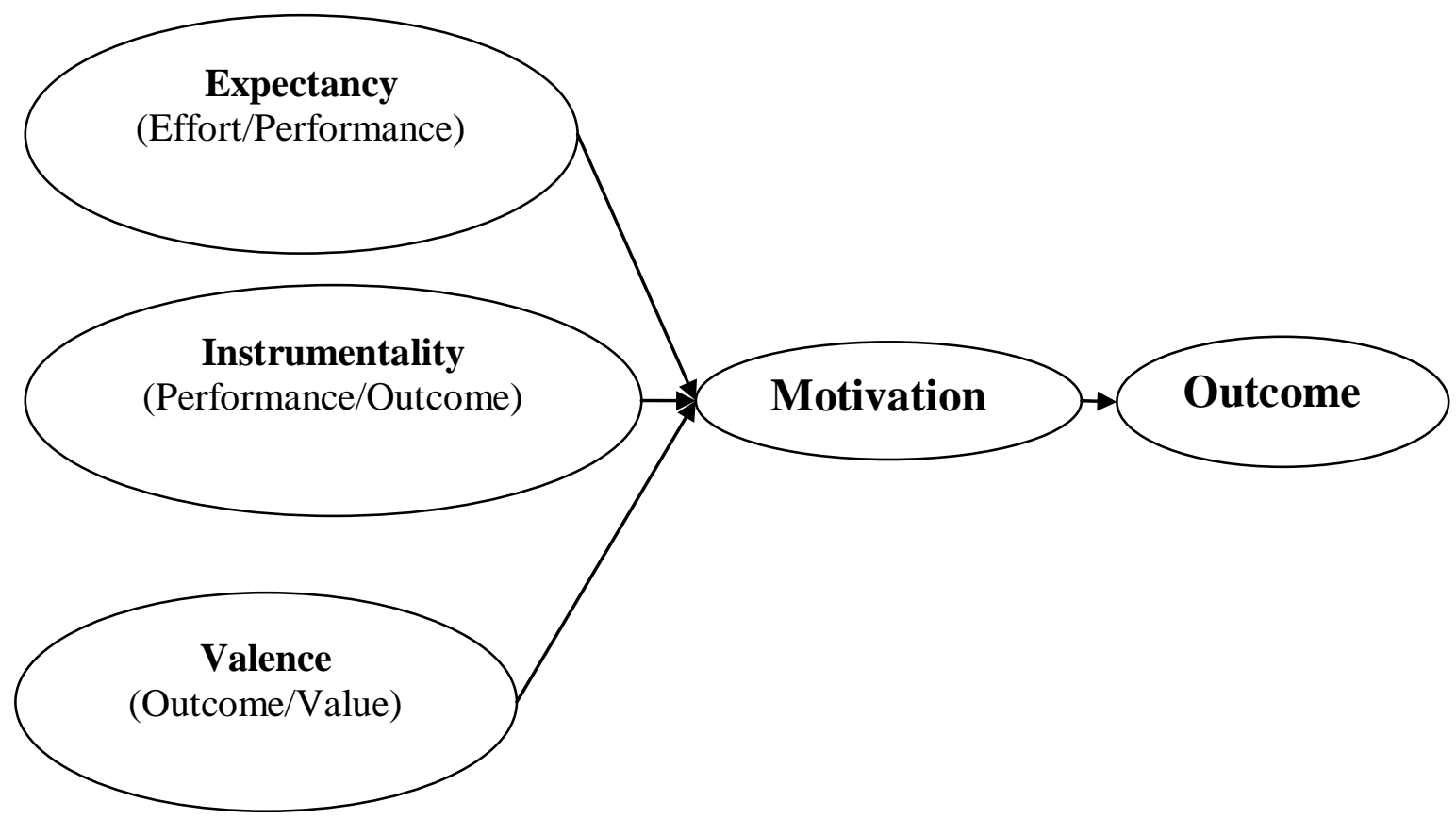

Figure 1:Vroom expectancy motivation model (VIE)

\section{Research Methodology}

The philosophical stance of this research is a positivist philosophy, upon which the methodology used in this research was a deductive approach concerned with developing hypotheses based on the existing theory underpinning this research. A quantitative technique through a cross-sectional survey was the designed research strategy to collect data and test the hypotheses of the research. The data were collected with a questionnaire as an instrument for the survey. To attain the objectives of this research, the data of this study were analyzed using PLS-SEM Path Algorithms, Bootstrap path coefficients and Sobel test statistics. The statistical significance of relevant path coefficients that are fundamental in measuring the influence of entrepreneurial motivation in self-employment among potential entrepreneurs were assessed and evaluated.

\section{Findings}

The findings of this research disclosed that potential entrepreneurs were being influenced mainly by the effect of expectancy and valence that streamline and spark the motivational elements in their new business start-up. Such expectance and valence include the need for independence, the desire for change, the need for poverty reduction, the need for more financial gain, the desire for a better condition of work, family commitments and the demand/market for their products. The expectancy and valence hold both financial and non-financial values. Consistent with Vroom's expectancy motivation theory, potential entrepreneurs find financial compensation as a motivating value (Vroom, 1964). This aligns with the notion that money is a motivating element for sparking commitment and efforts for starting a new business among potential entrepreneurs (Zanakis, Renko \& Bullough, 2012) Also, the finding suggests that for the potential entrepreneurs, other intrinsic values such as the desire for independence and the need for change are central to expectancy and valance in their new business start-up motivations and decisions. The perception that the new venture will achieve its fundamental aims rather than only financial gains seems to play significant role in their understanding of intrinsic rewards. This finding is consistent with past studies that indicate people attain to their expected attached values and attain their goals when they venture into a new business and with expected results that are consistent with their values (Canevello, 2011; Powell \& Eddleston, 2013;Seibert \& DeGeest, 2017).This indicates that the more the potential entrepreneurs have such belief, perception and expectation, the more they can realize the new venture creation and vice-versa.

Furthermore, external environmental factors such as vocational training, machinery/equipment and ICT's were found to significantly influence entrepreneurial motivation for an effective business start-up among the potential entrepreneurs. In line with the findings of this research, according to Dike (2013), result disclosed that, more importantly, entrepreneur's capacity is enhanced to facilitate an efficient production of their products if machinery/equipment is well provided and accessed. This portrays the essence of machinery/equipment in 
influencing the motivation of operations processes of businesses among the entrepreneurs. Also, Melia, Perez \& Dobon (2010), in an empirical investigation revealed that of entrepreneurs discovered that machinery/equipment in the operations processes is positively influencing the entrepreneurial motivation for effective self-employment among entrepreneurs. In their study, Maclean \& Wilson (2009) revealed that vocational training in providing employability stance and skills significantly influences influence the motivation of potential entrepreneurs for relevant occupational practices. As a mastery of a body of knowledge and skills that can be applied in a practical way, such vocational training program prepares a potential entrepreneur for a successful self-employment start-up (Scott \& Sarkees-Wircenski, 2008). Thus, in this direction, vocational training was found as a vital element in influencing the entrepreneurial motivation among potential entrepreneurs in self-employment realization (Biavaschi et al., 2012). In addition, the findings from Silva et al. (2010) further confirmed the results of this research in which they found a significant impact of the ICTs in supplementing the business processes by the entrepreneurs. The researchers reasoned based on the technological trends that engulfed the business environment, then such external factor (ICTs) was found to influences various contexts of business practices. This specifies that the more the potential entrepreneurs were supported with such external factors, the greater they can be motivated to realize a new business start-up and vice-versa.

4.1 Research Contributions

This research fills a gap and contributes to the theory and knowledge by exploring and showing how the effects of potential entrepreneur's motivation are channeled to behavioral outcomes in respect of a new business start-up. Explicitly, this study finds it rational to align the belief, perception and expectation upheld by the Vroom's expectancy motivation theory with other external factors such as vocational training, machinery/equipment and ICT's for an effective new business start-up among the potential entrepreneurs. Thus, holding such belief, perception and expectation by the potential entrepreneurs can be supplemented by theses external factors. In practice, the impact of these external factors will be of paramount importance in the realization of an effective venture creation witnessing the current changes in customer demands and trends in technology. In essence, this research has employed the combined and relative impact of both the internal and the external factors to measure self-employment. Thus, this could expand the generalization and the applicability of the Vroom's expectancy motivation theory in different entrepreneurship practices and contexts.

In addition, many studies have explored the empirical application of Expectancy Theory in the field of entrepreneurship (e.g. Gatewood et al.2012; Edelman et al.2010), but not all have demonstrated the interrelationships proposed by Vroom (1964). They generally confirm the basic assumptions in a variety of existing business operations (Renko et al. 2012; Ayodeji, 2051). This present research has applied the Vroom's expectancy motivation theory to investigate and measure a new business start-up. This contributes to knowledge.

4.2 Research Implications

A better understanding of the expectancy-instrumentality-valence bond and the overall motivation-driven process will benefit not only academic research, but also educationists, stakeholders, and policy makers who have a vested interest in encouraging new business start-up.Given considerations to the findings from this research, the current study has manifested a number of practical implications through the combined and relative influence of both the internal and the external factors in relation to entrepreneurship practices in the context of potential entrepreneurs in Bauchi State, Nigeria, and across different entrepreneurship practice context. This indicated that entrepreneurship stakeholders and the government can establish an entrepreneurial culture by giving due cognizance to both the internal and external factors optimally to ensure an effective self-employment practice. Thus, this suffices an implication to knowledge. In practice, it is essential for entrepreneurship stakeholders and the government to grasp the significant impact of these factors on potential entrepreneur's motivation in self-employment realization.

4.3 Research Limitations and Scope for Future Studies

Relatedly, this study focused exhaustedly on entrepreneurial motivation in assessing the context of self-employment outcome from the self-employment start-up perspectives. Thus, future research needs to focus on investigating entrepreneurial motivation in the context of existing businesses such as business performance, business growth and business sustainability (Jeremy et al., 2010; William et al., 2006; Taiyuan et al., 2017). Additionally, the present study employed a cross-sectional design to collect data which do not capture the data based on different time periods from the variables of interest and population. Hence, in future, a longitudinal research design needs to be employed in examining the constructs at different points in time. A longitudinal survey approach may help future researchers to collect more data on the variables of interest at different points in time. 


\section{Conclusion}

Motivation and decisions to act stem from a complex process that is a function of the person and the environment (Carsrud, Brännback, Elfving \& Brandt, 2017). Individual and environmental factors frequently result in influencing the motivations and choices with bounded rationality toward an expected valence or value (Hsu et al., 2014). The expectancy-instrumentality-valence mechanism investigated in this research suggests and discovered that potential entrepreneurs exert efforts and performance in realization of the expected valence (i.e., new business start-up) was triggered by their expectancy from such goal. Motivation and decisions to pursue new a new business is based on the expected value and probability of success. This evolves from the context of expectancy and valence, such as the need for independence, the desire for change, the need for poverty reduction, the need for more financial gain, the desire for a better condition of work, family commitments and the demand/market for their products. These values or factors all play a role in the complex motivation and decision process for a new business creation. Such findings create significant considerations forth generalization and applicability of the Vroom's expectancy motivation theory in various entrepreneurship practice contexts. The findings from this study can inform various stakeholders on the required factors and components for successful new business start-up. These factors can be both individual and environmental factors in making decisions on the essential elements to be mostly considered in providing support and motivation on what actually triggers efforts and performance in realization of the potential entrepreneur's new business start-up.

References

Ayodeji, M. (2015). Entrepreneurial development barriers in a developing nation: A Case Study of the Nigerian Printing SMEs.

Awruk, K \& Staniewski, M (2015). Motivating factors and barriers in the commencement of one's own business for potential entrepreneurs. Ekonomska istraživanja, 28(1), 583-592.

Canevello AJ. (2011). Interpersonal goals, others' regard for the self, and self-esteem: The paradoxical consequences of self-image and compassionate goals. European Journal of Social Psychology 41(4):422-434.

Carsrud, A., Brännback, M., Elfving, J., \& Brandt, K. (2017). Motivations: The Entrepreneurial Mind and Behavior in Revisiting the Entrepreneurial Mind (pp. 185-209). Springer International Publishing.

Fátima, M. J. A. (2012). On Becoming Self-Employed: Gender, Class and Entrepreneurship in Portugal. SSS.

Fitzsimmons, J. R., \& Douglas, E. J. (2011). Interaction between feasibility and desirability in the formation of entrepreneurial intentions. Journal of Business Venturing, 26(4), 431-440.

Fernández-Serrano, J., \& Romero, I. (2012). Entrepreneurial quality and regional development: Characterizing SME sectors in low income areas. Papers in Regional Science, 92(3), 465-513.

Gatewood, E. J., Shaver, K. G., Powers, J. B., \& Garner, W. B. (2012). Entrepreneurial expectancy, task effort and performance. Entrepreneurship Theory and Practice, 27(2), 187-206.

Henley, A. (2007). Entrepreneurial aspiration and transition into self-employment: evidence from British longitudinal data. Entrepreneurship \& Regional Development, 19(3), 253-280.

Hopp, C., \& Sonderegger, R. (2015). Understanding the dynamics of nascent entrepreneurship-Prestart-up experience, intentions and entrepreneurial success. Journal of Small Business Management, 53(4), 10761096.

Hsu, D. K., Shinnar, R. S., \& Powell, B. C. (2014). Expectancy theory and entrepreneurial motivation: A longitudinal examination of the role of entrepreneurship education. Journal of Business and Entrepreneurship, 26(1), 121-140.

Isa, Y. Z. M., Abu Bakar, Y. A., \& Ahmad, S. (2016). Determinant factors of women entrepreneurs' business performance: a conceptual framework. Journal of Global Business and Social Entrepreneurship, 1(1), 244-256.

Karimi, S., Biemans, H. J. A., Mahdei, K. N., Lans, T., Chizari, M. \& Mulder, M. (2017). Testing the relationship between personality characteristics, contextual factors and entrepreneurial intentions in a developing country. International Journal of Psychology, 52 (in press). Retrieved from http://onlinelibrary.wiley.com/doi/10.1002/ijop.12209/pdf

Kisker, C. E. W. (2016). Model for testing the impact of motivational factors of nascent entrepreneurs on business surviving success. European Scientific Journal, ESJ, 12(4), 126-132. 
Klyver, K., Nielsen, S. L., \& Evald, M. R. (2013). Women's self-employment: An act of institutional (dis)integration? A multilevel, cross-country study. Journal of Business Venturing, 28(4), 474-488.

Kritikos, A. S. (2014). Entrepreneurs and their impact on jobs and economic growth. IZA World of Labor.

Manolova, T. S., Brush, C. G., Edelman, L. F., \& Shaver, K. G. (2012). One size does not fit all: Entrepreneurial expectancies and growth intentions of US women and men nascent entrepreneurs. Entrepreneurship \& Regional Development, 24(1-2), 7-27.

Manolova, T. S., Brush, C. G., \& Edelman, L. F. (2007). What do women (and men) want? Entrepreneurial expectancies of women and men nascent entrepreneurs. Frontiers of Entrepreneurship Research, 27(8), Article 2.

Powell GN, Eddleston KA. (2013). Linking family-to-business enrichment and support to entrepreneurial success: Do female and male entrepreneurs experience different outcomes? Journal of Business Venturing28(2), 261280.

Seibert, S. E., \& DeGeest, D. S. (2017). The Five Factor Model of Personality in Business and Industry. The Oxford Handbook of the Five Factor Model, 381.

Shapiro, A. F. (2014). Self-employment and business cycle persistence: Does the composition of employmentmatter for economic recoveries?Journal of Economic Dynamics and Control, 46, 200-218.

Sozen, E., \& O'Neill, M. (2017). An Exploration of the Motivations Driving New Business Start-up in the United States Craft Brewing Industry. In Craft Beverages and Tourism, Volume 2 (pp. 195-212). Palgrave Macmillan, Cham.

Thurik, A. R., Carree, M. A., Van Stel, A., \& Audretsch, D. B. (2008). Does self-employment reduce unemployment?. Journal of Business Venturing, 23(6), 673-686.

Vroom, V. H. (1964).Work and motivation. New York: Wiley.

Vroom, V. H., \& Jago, A. G. (1978). On the validity of the vroom-Yetton model. Journal of Applied Psychology, 63(7), 151-162.

Yushuai, W., Na, Y., \& Changping, W. (2014). An Analysis of Factors Which Influence Entrepreneurial Motivation Focused on Entrepreneurs in Jiang Xi Province in China. Journal of Applied Sciences, 14(8), 767-775.

Zanakis, S. H., Renko, M., \& Bullough, A. (2012). Nascent entrepreneurs and the transition to entrepreneurship: Why do people start new businesses? Journal of Developmental Entrepreneurship, 17(1), 1-25

\section{Copyrights}

Copyright for this article is retained by the author(s), with first publication rights granted to the journal.

This is an open-access article distributed under the terms and conditions of the Creative Commons Attribution license (http://creativecommons.org/licenses/by/4.0/) 